\title{
PSYCHOSOCIAL ASPECTS OF STRESS \\ IN CURRENT UNIVERSITY STUDENTS
}

\author{
Jana Kvintová \\ Martin Sigmund
}

\begin{abstract}
The presented article deals with current issues of contemporary university students in the context of the effects of psychosocial aspects of stress. University students represent a specific population group, which is influenced by multiple stressors associated with the transition from the high school to university environment, problems of adaptation to the new environment associated with the academic load, the transition from adolescence to adulthood associated with accepting new roles, the anticipation of the future associated with fulfillment of the social expectations, etc. The existing research shows that the student population has poorer health than the non-studying population of the same age. Analyzing the profile of a university student appears to be an important aspect that can contribute to the creation of preventive programs to reduce or compensate the burden in the student's population and to identify topics for effective intervention in university counseling.
\end{abstract}

\section{Key words}

Psychosocial stress, health, personality, university students.

\section{THE DISTRESS IN CURRENT UNIVERSITY STUDENTS}

Issues of stress and stressful situations are frequent scientific research questions in the realm of psychology. The current state of knowledge and the findings of contemporary scientific literature point to the theoretical and practical need to continue the research into psychological stress - especially the issue of coping with various forms of stress. Recently, there has been growing interest in the health status of university students - especially as they represent a national investment in the future.

From an evolutionary perspective the student is an individual whose age is characterized by reaching maturity in the somatic, mental, emotional and social areas. It is generally indicated that the population between the twentieth and thirtieth year of life is a group with the lowest morbidity and mortality. It should be emphasized that research results which analyze risk factors with regard to the university population, warn that the health status of university students is generally worse than the health status of non-studying population of the same 
age. Also, the prevalence of psychological distress is higher among university students than in the working population of the same age (Roberts, Golding, Towell, Weinreb, 1999; Adlaf, Gliksman, Demers, Newton-Taylor, 2001; Dyrbye, Thomas, Shanafelt, 2006).

Provazníková et al. (2002) attempted to analyze the main risk determinants of health in the student population. Results of this research conducted at five different faculties (sample - 410 participats) related to the question about subjective evaluation of their health, point out that although $46 \%$ of students feel healthy and $48 \%$ of students rather healthy, at the same time there is found a number of psychosomatic symptoms. These symptoms are caused by stress and anxiety feelings associated on one hand with problems in some area of life (family, partnership) and often on the other hand with studies at university.

Therefore, in order to be a successful student and cope with the various demands of university life, students should ideally be physically and psychologically healthy. If the burden for university student becomes disproportionately high, a failure in adaptation will occur, which will result in the disruption of at least one of the structures of individual interaction with the environment. Undesirable changes may occur at the level of physical, biological, interpersonal, or socio-cultural.

Factors that affect the health of students are very specific and it is assumed that they are closely associated with being a university student. Thereby, the main stressogenic factors are considered to be academic overload, constant pressure to be successful and competitiveness with classmates. In some countries, we furthermore find evidence of financial constraints and concerns about the future (Lu, 1994; Omigbodum et al., 2006, Lee et al., 2007). But undesired stress affects not only the health of the student, but his academic performance as well (Hamaideh, 2011). In addition to general academic stress, other factors include the effects of sexual relations, the nature of the subject major, the overall duration of the studies, various social adjustment factors, and personality characteristics.

In particular, the issues of the relation among intersexual differences and individual coping strategies show relatively ambiguous conclusions (Stern et al., 1993; Renk, Creasey, 2003). Some comparative studies have consistently reported a higher frequency of psychological distress in women than in men (Hankin, Abramson, 1999; Denon, Prus, Walter, 2004). Based on these findings we may see differences in the perception of stressful situations and, consequently, differences in terms of coping strategy preferences. 


\section{THE PSYCHOSOCIAL ASPECTS OF STRESS AMONG UNIVERSITY STUDENTS}

In scientific literature we can find many studies and notable research that deal with the issue of elevated stress levels amongst university student. Mostly, however, they focus on selected indicators that refer to specific variables. Comprehensive work on this topic is somewhat less prevalent. In domestic scientific literature there is a general lack of current psychological publications of a monographic type related to a more comprehensive concept of the problems of university students. Earlier work has not fully reflected the present picture of this issue (Páričková, 1987; Grác, 1981). However, there is partial research and studies that address this topic and they give us the basis for a psychological and social profile of current college students and for comparison with our experience and knowledge (Konečný, 1996; Provazníková, Štullerová, Provazník, Hynčica, 1999; Mikšík, 2002; Plichtová, Keresztesová, 2004; Kožený, Tišanská \& Höschl, 2004; Menclová, Baštová, 2005; Linhartová, 2008; Šolcová, Kebza, 2009; Plháková, Reiterová, 2010).

Sociological research presents permanent up-to-dateness and the importance of this issue- a focus on the life of university students. As the main subject of the research questions sociologists state an analysis of their social, economic and educational conditions. Especially in conditions of several changes, the offer of educational services is changing, the concept of university education policy is changing and also last but not least there are the social changes (Menclová, Baštová, 2005; Menclová et al., 2003). Certain burden might represent for example a change of career orientation, the student who has already begun the study must solve the issue of the future success on the labor market. The research dealing with the social profil of a university student shows that the student who is studying at typical state university is single, childless, with a mean age of 24 years and lives mainly in dormitories.

Studies related to mainly socio-economic conditions in university studies are conducted by a specialized institution "Centre for the Study of Higher Education". The results of studies (Menclová et al., 2003; Menclová, Baštová, 2005) for example show the following findings:

- Social background in families of students partly determines the chosen major and the tendency to studies university. Adolescents from families with university - educated parents (mostly fathers) are the most represented in the most desirable faculties, especially the medical and law faculty (i. e. in 2001, these students made up $58 \%$ of the students studying at the medical school and $64 \%$ of students at the law school).

" Financial cost of a university education is increasing. University student needs at least 5,600 Czech crowns for transportation, food, books and housing per month, which means that up to two thirds of students must compensate the difference between the contribution from the parents and the real cost by occasional job. 
" The proportion of students living with their parents has a decreasing tendency, research from 2005 indicates that about $27-39 \%$ of students remaining in their original home.

The transition from high school to an university environment can cause individuals considerable psychosocial burden. This fact is also confirmed by numerous studies that refer to this transition period as a critical period in the life of the student. The emrollment at university for many students is a significant change in life and work style. Some are also associated with a change of residence and even a change of position in the current family. This transition means that the individual must adapt to a new situation and environment. The aim of this adaptation in a favorable case is a degree of student identification with the school and its culture. Identification is achieved in several forms - as natural identification, selective identification (acceptance of value framework and standards to varying degrees) and calculated identification (study's purpose). Various forms of identification are achieved in a gradual process of adaptation, which starts from the admission process.

Konečný (1996) describes the significant changes that occur with commencing the study in the context of loss and discovery. These changes are specified as:

" The loss, termination or reduction of certain existing possibilities, which means limited contact with family, environmental change, that is connected with the loss of privacy, material equipment, limited contact with friends or partners and limited hobby activities.

" The emergence of new demands, claims, conditions which the student must face. They relate mainly to the higher demands on quatity of study knowledge, higher demands on independent preparation, processing the knowledge, and higher demands on paying attention during lessons.

In the process of adaptation the first year of study appears to be the most stressful, with all claims, difficulties and problems appear in a short time interval. There are two basic issues, already mentioned need for orientation in the new environment, knowledge claims and responses to them. The second problem is the coexistence with students in dormitories, integration into the society of other students, creating a new social networks and acceptance of the role of colleague student. These aspects are confirmed by (2008) and they still add that students living in dormitories are at greater risk of unwanted stress, adaptation and mental health problems than students who live outside the college. For students whose residence is unchanged, some of these problems do not occur, they experience less change and adaptation for entering the university is more harmonious. Some studies also point to the fact that better socioadaptation to the university environment is affected by financial aspects, so called "higher material well-being" (Batrymbetova, 2008). 
In terms of carring out the academic duties related to the study, the actual exam stress represents an important factor. It consists of a wide range of stressful situations, which a university student is exposed to. The stress associated with various forms of exams can reduce overall performance. At the same time the risk of susceptibility to disease increases, because it reduces the immunological parameters and increases cardiovascular activity (Carreras, Castro, 1998). Thus academic stress affects the overall behavior of university students. In periods of increased stress it leads to worsening of the nutrition quality and physical activity. The overall care of oneself is reduced, there is a drop in good mood and an increase of negative emotions. Also during this period it is found a higher adherence to substance use.

A wide variety of tests and situations associated with the evaluation of performance play a major role in the student's academic career. Therefore, effective management of these situations appears to be crucial for coping with academic demands and maintaining mental health of the student. Most students experience some anxiety during the test period. However, some students experience high anxiety that deteriorates their performance in the test. On average, it is stated that $25-30 \%$ of college students reported high levels of test anxiety.

Schuller (1994) points out that the fear factor from the test situation is one of the important manifestations in the school environment. It is a part of important relationships with authority figures at school; it is a problem to control oneself, social relationships and physical sensitivity to environmental factors, where the actual testing takes place. Each test is associated with the concept of potential failure, social risk, and therefore causes the increased excitement, nervousness and stage fright. According to Kondáš (1979, p.179) in the formation of the stage fright there is a contribution of multiple factors. The most important factors are listed:

- Personal assessment of the significance of performance situation.

$\rightarrow$ Demands of the situation in relation to the possibilities of self-realization.

" The concept of uncertainty and possible failure.

$\rightarrow$ The threat of failure and mockery.

$\rightarrow$ Anxiety, emotional lability, nervousness and irritability.

In her study focused on issues of university education Linhartová (2008) refers to surveys from the Faculty of Education in Prague in the years 2000 and 2002, which also deal with psychological characteristics. Their focus was mainly on personality traits. The results characterize a student as more open, more critical, even very critical, with considerable confidence, using assertive behavior, with good language skills and well oriented in information technologies. In opposition to these personality traits there is lesser autonomy and responsibility. 


\subsection{Adolescent, or adult?}

From the ontogenetic point of view, a college student is on the verge of two important developmental stages. The individual in this age group is leaving the period of adolescence and entering the period of adulthood, or rather younger adulthood. These developmental aspects bring the individuals in this period into both a positive and a negative confrontation with the reality of life. The period of adolescence must be mentioned because the student coming to university is found at the transition of two developmental periods - adolescence and young adulthood. Adolescence falls within the age range from $16-17$ to 19 years of age (Binarová, 1999). Kuric (2001) indicates the upper limit of this period between 18 and 21. The main task of adolescence by Kuric (2001) is the preparation for a profession commensurate with individual abilities and mental maturation. The individual has to cope with many life problems, set a life goal and tasks for the preparation of a future occupation. Generally, an adolescent does not often have clear-cut interests, does not know in what field he would like to realize his/her potential and be successful. There may be a conflict of interest and ideas between the adolescent and his/her parents. Social pressure regarding social status, economic independence and success is today much stronger than it was before. Education in general is a factor that plays a role in choosing a partner, family stability and creating a frame of reference for educational reproduction (Cakirpaloglu, Řehan, 2000).

For university students beginning their studies, the period of adolescence is extended and such an individual remains in many respects bound to its primary family, both socially and mainly materially. Slepičková (2001) estimates that by studying at university the student postpones entry into the adult life of $4-6$ years. Research has shown that significant and long-term dependence on one's own family is more evident in girls than in boys; there is significantly higher social pressure put on boys' independence (Binarová, 1999). During this period, the individual creates their own values and their own opinions of societal affairs, thereby becoming more independent of parental authority.

They do not have the need to spend so much time with their parents and relationships with peers and establishing new partnerships become more important. An individual gets into a situation where on one side they want to become independent and make decisions for themself, but on the other hand, are still largely materially dependent on their parents. Many students come to university burdened by the so-called residues of previous life stages, which take on the form of unfulfilled tasks of psychosocial, psychosexual and cognitive development. Admission to university is a difficult period - an inner journey of self-development, combined with finding oneself and answers to questions of who and what I am, what I want, what I can do, and what I can believe in (Hargašová, 1992). This process of forming one's identity is also accompanied by a strong need for inclusion, a sense of community and continuity in relationships and time, the so-called social aspects of identity. 


\subsection{Motivational factors}

Among Czech university students in the $80^{\text {th }}$ of the $20^{\text {th }}$ century in terms of motivational factors for selection of the university education there was not yet put the emphasis on financial benefit of this career choice. According to Grac (1981) the typical preferences for motivation were internal motives (79\%) prior to external. This is confirmed by Kohoutek (1998) describing the main elements of motivation, such as needs of personality cultivation, application of individual abilities and interests, and on the third place it was a need to achieve the specialization.

At the present time, the main factors motivating students to enter university are relatively clearly structured (Linhartová, 2008). Primarily it is to obtain education as the possibility for a successful professional career and well-paid work. Accompanying features of these factors are obtaining a university degree and good status in society. The most common problems during the study include lack of finance, combining occasional work and study, complicated commuting and completing exams and obtaining credits.

In terms of factors influencing the dynamics of motivation for learning it can be stated that in the last ten years, although the order of their preferences does not change, but the trend has downward character. Repeated sociological investigations still state the good job and career as the main motivating factor. University degree and position in society also have an irreplaceable role in the motivation to study. Respondents frequently cited the development of education and postponement of practical experience. The most declining motivational factor is the self-interest in the field. Virtually since 1998, the motivational curve (of self-interest) has been quite sharply decresed. Thus, the actual field and its internalization with it in the current students do not appear as a significant motivating factor. The only motivator, that since 1995 has not registered a decrease and as the only one has a relatively stable character in the developmental curve, is the family tradition; the currently there has even been an increase (Menclová, Baštová, Konrádová, 2003; Menclová, Baštová, 2005).

In motivational factors Gurova and Dermendjieva were also engaged (in Linhartová, 2008); they described three categories of university students in terms of different sources of motivation to study. The first group consists of students whose motivation to study is unstable and for the university they decided mainly from external causes, such as pressure of their parents or postponing the entering to employment. The second category are students with a pragmatic orientation, for which obtaining a university degree means higher social prestige or social establishment of useful contacts. The last group consists of students with high positive motivation, who are interested in a profession or field and knowledge means to them a high value. 


\subsection{Personality traits and coping with stress}

Kohoutek (1998) elaborates relatively in details the ways of self-knowledge and self-education among university students and emphasizes that the skill of a student to independently evaluate his focus to the target and his options, put them into a relationship with adequate external conditions and requirements of environment, is of a great importance in shaping the student's own personality. Here, however, much depends on the level of autonomy of set targets, as heteronomous goals after graduation are no longer subjectively important. Social maturity of the personality is characterized by the relationship of the student and his assumptions, potential strengths and weaknesses.

In recent years, growing evidence has accumulated showing that personality is related both to stress and to coping. Initially, there were the two basic personality factors from Eysenck's system - Neuroticism and Extraversion that turned out to be important predictors of stress and coping. Neuroticism predisposes people to experience more distress and negative emotions, whereas persons high in Extraversion are predisposed them to experience positive affects (Boler, Schilling, 1991). Later on, the attention has started to focus on five personality dispositions comprising the "Big Five" traits in the Five Factor Model of personality (Openness to experience, Conscientiousness, Extraversion-Introversion, Agreeableness, and Neuroticism-Emotional stability) (Farsides, Woodfield, 2003). Several studies found that Conscientiousness is strongly related to coping, especially there is a positive correlation to active problem solving, refraining from passive maladaptive coping, and planning. Vollrath and Torgersen (2000) found in their research focused on university students, that the most favourable profile of stress and coping show persons with combination of low Neuroticism and high Conscientiousness. Whereas students high in Neuroticism and at the same time low in Conscientiousness show high vulnerability to stress and poor coping. The effects of Extraversion is more ambiguous.

\section{CONCLUSION}

If we in terms of psychology attempt to summarize the basic characteristics, it is necessary to state that university students represent a specific population group that is exposed to multiple stressors. These stressors are mainly a combination of influences such as transition from the high school to university environment, problems of adaptation to new environments associated with the academic load, the transition from adolescence to adulthood associated with acceptance of new roles, the anticipation of the future associated with fulfillment of social expectations, etc. The variability of psychological factors and different levels of experienced distress can affect a verifiable fact that the overall health of university students is worse than health status of non-studying population in the same age. 
For successful termination of university studies while maintaining a reasonable good health, some of the essential factors seem to be the personality structure and dynamics. Personality variables can significantly contribute to the coping with stressful situations, which the college students are exposed to and simultaneously manage the important period of the transition from adolescence to adulthood. Personality traits in terms of stress are reflected in the processes of coping with stress. They decisively affect the evaluation of stressogenic situations and choice of coping strategies, and thus the subsequent psychological processes (e.g, emotions) as well and its neuroendocrine component. Certain personality traits predispose to a particular style of evaluation and management of stress and may be the explanation of different interindividual vulnerability to stress (Bolger, Schilling, 1991; Kebza, Šolcová, 2003). Analyzing the profile of a university student can make an important contribution to the creation of modern prevention programs focused on student's workload and to identification of topics for university counseling.

\section{List of literature and professional sources}

Adlaf, E. M., Gliksman, L., Demers, A., \& Newton-Taylor, B. (2001). The Prevalence of Elevated Psychological Distress among Canadian Undergraduates: Findings from the 1998 Canadian Campus Survey. Journal of American College Health, 50, pp. 67-72.

Batrymbetova, S. A. (2008). The Medical Social Factors of Students' Health. Probl Sotsialnoi Gig Zdravookhranenniiai Istor Med, Sep-Oct, 5, pp. 9-11.

Binarová, I. (1999). Období adolescence. In Šimíčková-Čížková, J. a kol. Přehled vývojové psychologie. UP Olomouc, Olomouc.

Bolger, N., \& Schilling, E. A. (1991). Personality and the Problems of Everyday Life: The Role of Neuroticism in Exposure and Reactivity to Daily Stressors. Journal of Personality, 59, 3, pp. 355-386.

Cakirpaloglu, P., \& Řehan, V. (2000). Determinanty a efekty sociální stratifikace mladých lidí v České republice. Českoslovenká psychologie, 44, 2, pp. $110-131$.

Carreras, P., \& Feranandes-Castro, J. (1998). Adaptation to Examination Stress in First and Second Year University Students. Studia psychologica, 40, 3, pp. 181-186.

Denon, M., Prus, S., \& Walter, V. (2004). Gender Differences in Health: a Canadian Study of the Psychosocial, Structural and Behavioural Determinants of Health. Social Science\& Medicine, 58, pp. 2585-2600.

Dyrbye, L. N., Thomas, M. R., \& Shanafelt, T. D. (2006). Systematic Review of Depression, Anxiety, and Other Indicators of Psychological Distress among U. S. and Canadian Medical Students. Academic Medicine, 81, pp. 354-373.

Farsides, T., \& Woodfield, R. (2003). Individual Differences and Undergraduate Academic Success: the Roles of Personality, Intelligence, and Application. Personality and Individual Differences, 34, 7, pp. 1225-1243. 
Grác, J. (1981). Psychológia vysokoškolského študenta. Osveta, Bratislava. s. 176. Hankin, B. L., \& Abramson, L. Y. (1999). Development of Gender Differences in Depression: Description and Possible Explanations. Annals of Medicine, 31, pp. 372-379.

Hamaideh, S. H. (2011). Stressors and Reactions to Stressors among University Students. International Journal of Social Psychiatry, Jan; 57, 1, pp. 69-80.

Hargašová, M. (1992). Problémy adaptácie študentov na vysokú školu. Ústav informácií a prognóz školstva, mládeže a telovýchovy, Bratislava.

Hicks, T., \& Heastie, S. (2008). High School to College Transition: A Profile of the Stressors, Physical and Psychological Health Issues That Affect the First-Year On-Campus College Student. Journal of Cultural Diversity, 15, 3, pp. 143-147.

Kohoutek, R. (1998). Osobnost a sebepoznání studentů. Akademické nakladatelství CERM, Brno. ISBN 80-7204-087-1.

Kondáš, O. (1979). Strach zo skúšky. SPN, Bratislava. s. 199.

Konečný, J. (1996). Psychologická hlediska problémů při studiu na vysoké škole. In Konečný, J. a kol., Úvod do vysokoškolského studia. RUP, Olomouc.

Kožený, J., Tišanská, L. \& Höschl, C. (2004). Predikce akademického výkonu a úspěchu studentů medicíny v prvních deseti semestrech studia. Československá psychologie, 48, 6, pp. 491-498.

Kuric, J. (2001). Ontogenetická psychologie. Akademické nakladatelství CERM, s. r. o., Brno.

Lee, BS., Kang, SR., Kim, HO (2007). Experience of job satisfaction in clinical nurses: application of focus group metodology. Taehan Kanho Hakhoe Chi, 37, pp. 114-124.

Linhartová, D. (2008). Vysokoškolská psychologie. MZLU, Brno.

Luo Lu. (1994). University Transition: Major and Minor Life Stressors, Personality Characteristics and Mental Health. Psychological Medicine, 24, 1, pp. 81-87.

Menclová, L., Baštová, J., \& Konrádová. K. (2003). Vysokoškolský student v České republice roku 2002. MŠMT, VUTIUM, VUT Brno.

Menclová. L., Baštová, J. (2005). Vysokoškolský student v České republice roku 2005. MŠMT, Praha. ISBN 80-86302-35-0.

Mikšík, O. (2002). Sebepojetí manifestované uchazeči o studium psychologie v procesu přijímacího řízení. Československá psychologie, 46, 2, pp. 109-119.

Omigbodun, O. O., Odokogbe, A. T., Omigbodun, A. O., Yyusuf, O. B., Bella, T. T., \& Olayemi, O. (2006). Stressors and Psychological Symptoms in Students of Medicine and Allied Health Professions in Nigeria. Social psychiatry and psychiatric epidemiology, 41, 5, pp. 415-21.

Páričková, I. (1987). Vývinové špecifiká potrieb vysokoškolákov. In Universitas Comeniana Psychologica 23. SPN, Bratislava.

Plháková, A., \& Reiterová, E. (2010). Rozdíly v pěti dimenzích osobnosti a sociální inteligenci mezi studenty exaktních a humanitních věd. Československá psychologie, 54, 2, pp. 147-159. 
Plichtová, J., \& Keresztesová, K. (2004). Práva a zodpovednosti v diskurze bratislavských vysokoškolákov. Československá psychologie, 48, 5, pp. 416-432.

Provazníková, H., Schneiderová, D., Valenta, V., \& Hynčica, V. (2002). Determinanty zdraví vysokoškolských studentů. Vita nostra revue, 2, 69-75.

Provazníková, H., Štullerová, N., Provazník, K., \& Hynčica,V. (1999). Vliv studijních a životních podmínek na zdravotní stav a studijní úspěchy vysokoškoláků. Psychológia a patopsychológia dietata, 25, 6, pp. 501-511.

Renk, K., \& Creasey, G. (2003). The Relationship of Gender, Gender Identity, and Coping Strategies in Late Adolescents. Journal of Adolescence, 26, 2, pp. $159-168$.

Roberts, R., Golding, J., Towell, T., \& Weinreb, I. (1999). The Effects of Economic Circumstances on British Students' Mental and Physical Health. Journal of American College Health, 48, pp. 103-109.

Schuller, S. I. (1994). Load and Stress in School - their Sources and Possibility of Coping with Them. Studia psychologica, 36, 1, pp. 41-52.

Stern, M., Norman, Sloan, L., Komm, Ch. (1993). Medical Students' Differential Use of Coping Strategies as a Function of Stressor Type, Year of Training, and Gender. Behavioral Medicine, 18, 4, pp. 173-180.

Šolcová, I., Kebza V. (2009). Osobní pohoda vysokoškolských studentů: česká část studie. Československá psychologie, 53, 2, pp. 129-139.

Vollrath, M., \& Torgersen, S. (2000). Personality Types and Coping. Personality and Individual Differences, 29, 2, pp. 367-378.

\section{Contact:}

PhDr. Jana Kvintová, Ph.D.

Department of Psychology and Pathopsychology

Faculty of Education, Palacký University Olomouc

Žižkovo nám. 5, 77140 Olomouc

Czech Republic

E-mail: janakvintova@seznam.cz, Phone: +420-585 635203

PhDr. Martin Sigmund, Ph.D.

Department of Recreology

Faculty of Physical Culture, Palacký University Olomouc

Tř. Míru 115, 77111 Olomouc

Czech Republic

E-mail: martin.sigmund@upol.cz, Phone: +420-585 636157 